\title{
Knowledge regarding 2019 novel coronavirus (2019-nCoV) infection among final year health science students at Arbaminch College of Health Sciences, Southern Ethiopia: a cross-sectional study
}

Biruk Wogayehu ( $\sim$ biruk900zelalem@gmail.com )

Arbaminch college of health sciences

Wondimagegn Taye

Arbaminch college of health sciences

Yilma chisha

Arbaminch University

Kahssay Faraja

Arbaminch college of health sciences

\section{Research Article}

Keywords: Pandemic, novel Coronavirus, Knowledge, Health science students, Ethiopia

Posted Date: April 25th, 2020

DOl: https://doi.org/10.21203/rs.3.rs-24777/v1

License: (c) (i) This work is licensed under a Creative Commons Attribution 4.0 International License.

Read Full License 


\section{Knowledge regarding 2019 novel coronavirus (2019-nCoV) 2 infection among final year health science students at 3 Arbaminch College of Health Sciences, Southern Ethiopia: a 4 cross-sectional study}

5 Biruk Wogayehu ${ }^{1 *}$, Wondimagegn Taye ${ }^{2}$, Yilma Chisha ${ }^{3}$, Kahssay Faraja ${ }^{4}$

6 'Pharmacy department, Arbaminch College of Health Sciences, Arbaminch town, Southern state, Ethiopia

$7 \quad{ }^{2}$ Public health department, Arbaminch College of Health Sciences, Arbaminch town, Southern state, 8 Ethiopia

$9 \quad{ }^{3}$ Public health department, Arbaminch University, Arbaminch town, Southern state, Ethiopia

$10{ }^{4}$ Clinical nursing department, Arbaminch College of Health Sciences, Arbaminch town, Southern state, 11 Ethiopia

$14 *$ Correspondence author

15 E-mail: biruk900zelalem@gmail.com(BW)

16

17

18

19

20

21

22

23

24 


\section{Abstract}

\section{0}

\section{Introduction}

In January 2020, World Health Organization declared the outbreak of novel coronavirus a pandemic (global health emergency). The aim of this study was to assess the knowledge about novel coronavirus and its determinant factors among health science students at Arbaminch Health Sciences College, Southwest Ethiopia.

\section{Method}

A cross-sectional study design was employed to assess the level knowledge about novel coronavirus among 304 graduating class students in Arbaminch Health Science College. The study participants were selected using a simple random sampling technique. The data collection tool consisted of 33 items (10 items about demographic and education related and 23 items about knowledge on novel coronavirus). Multivariable logistic regression was performed using SPSS.

\section{Results}

The vast majority of students $228(75 \%)$ scored below $50 \%$ and were considered to have poor knowledge on COVID-19. Only $7.6 \%$ of participants knew that muscle pain is a symptom of 2019-nCoV infection. One hundred forty three (47\%) of the participants did not know any symptoms of COVID-19. Only $24.3 \%$ of the respondents answered correctly that rubbing hands with alcohol based sanitizers can help in prevention of disease transmission. Sex, residence and social media use were significantly associated with adequate knowledge on novel coronavirus ( $\mathrm{p}$ $<0.05)$.

\section{Conclusion}

Health science students had poor knowledge on COVID-19. The health science college and health authorities should re-examine their capability to manage the deadly virus

\section{Key words}

Pandemic, Novel coronavirus, Knowledge, Health science students, Ethiopia 


\section{Introduction}

54 Coronaviruses are a huge group of viruses that can cause a variety of diseases in humans, from 55 the common cold to severe acute respiratory syndrome (SARS) [1]. In December 2019, the first 56 case of the novel corona virus (the seventh type coronavirus) reported in Wuhan city, Eastern 57 China was presented by acute respiratory symptoms [2]. The novel coronavirus also named as SARS-CoV-2. In February 2020, World Health Organization (WHO) named the infection 59 coronavirus disease 2019(COVID-19) [3]. Shortly, the disease has spread throughout the globe. In January 2020, WHO declared the outbreak of novel coronavirus a pandemic (global health emergency) [4]. As of March 13, 2020, a total of 132, 758 laboratory-confirmed cases and 4955

62 deaths had been documented globally. The WHO situational report-53 also revealed that 80,9991

63 cases in China, 7979 cases in Republic of Korea, 15,113 cases in Iran, 2965 cases in Spain,

6415,113 cases in Italy and 25 cases in Algeria[5].

February 24, 2020, 2055 healthcare professionals had confirmed infected with novel coronavirus infection, with $1.1 \%$ deaths in China [6]. A study conducted by Gilbert and colleagues revealed that Ethiopia and Nigeria were the countries with second highest importation risk [7].

March 13, 2020, the Federal Ministry of Health reported on one individual with confirmed coronavirus disease from the capital city of the country, Addis Abba [8]. The number of confirmed cases of novel coronavirus disease in Ethiopia has since increased.

Health care professionals are at the first line of outbreak response and as such are exposed to corona virus. Special consideration should be paid to health science students seeing their contribution to the nation's workforce in near future in a particular nation. Moreover, there is no any study assess the knowledge level on novel coronavirus among health science students in Ethiopia. Therefore, the objective of this study was to assess the knowledge about novel corona virus and its determinant factors among health science students at Arbaminch Health Science College, South west Ethiopia.

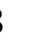

9

81

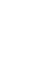

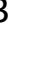

4


Methods

Study setting and period

87 The study was conducted from March 14 to April 05, 2020 in Arbaminch Health Science College. Arbaminch Health Science College was established in 2005 and found in Arbaminch city, southern part of Ethiopia. The college has six departments (Pharmacy, Medical laboratory, Health extension, Clinical nurse, Health informatics and Midwifery). The mission of the college is to train qualified mid-level health care professionals or technicians. There were 980 graduate class students in regular and private program during the study period. Study design

A cross-sectional study design was employed to assess the level knowledge about novel coronavirus among graduating class students in Arbaminch Health Science College.

\section{Study participants}

Our source population was all final year ( $3^{\text {rd }}$ year) health science students in Arbaminch Health Science College. The study population was all final year health science students in the College who were available in the college during the data collection period.

\section{Inclusion and exclusion criteria}

Inclusion criteria

Final year students who were registered in Arbaminch Health Science College in the first semester of 2019/2020 academic year.

\section{Exclusion criteria}

Graduating class students who were not physically capable of being interviewed at the period of data collection were excluded from the study.

\section{Sample size and sampling procedures}

Since there is no previous research on knowledge about novel coronavirus in similar areas, to get most favorable sample size, calculation was performed using the assumption of proportion (p) of students without sufficient knowledge on corona virus 50\%, with $95 \%$ CI and $5 \%$ marginal error.

$$
\mathrm{n}=\frac{\mathrm{Z}^{2} \alpha_{/ 2} \mathrm{p}(\mathrm{p}-1)}{\mathrm{d}^{2}}=384
$$

Since the number of graduating class students in the college is less than 10,000 , correction formula was employed.

$$
n f=\frac{n}{1+n / N}=384 / 1+384 / 980=276
$$


Hence, the minimum sufficient computed sample size was 304 including $10 \%$ non-response rate. Strata were made based on departments and sampling frame was organized using identification numbers of graduating class students taking from the college registrar office. The study participants were taken from the six departments (Pharmacy, Medical laboratory, Clinical nurse, Midwifery, Health extension and Health informatics department) using stratified random sampling with proportional allocation. The study participants were selected using a simple random sampling technique (Figure 1).

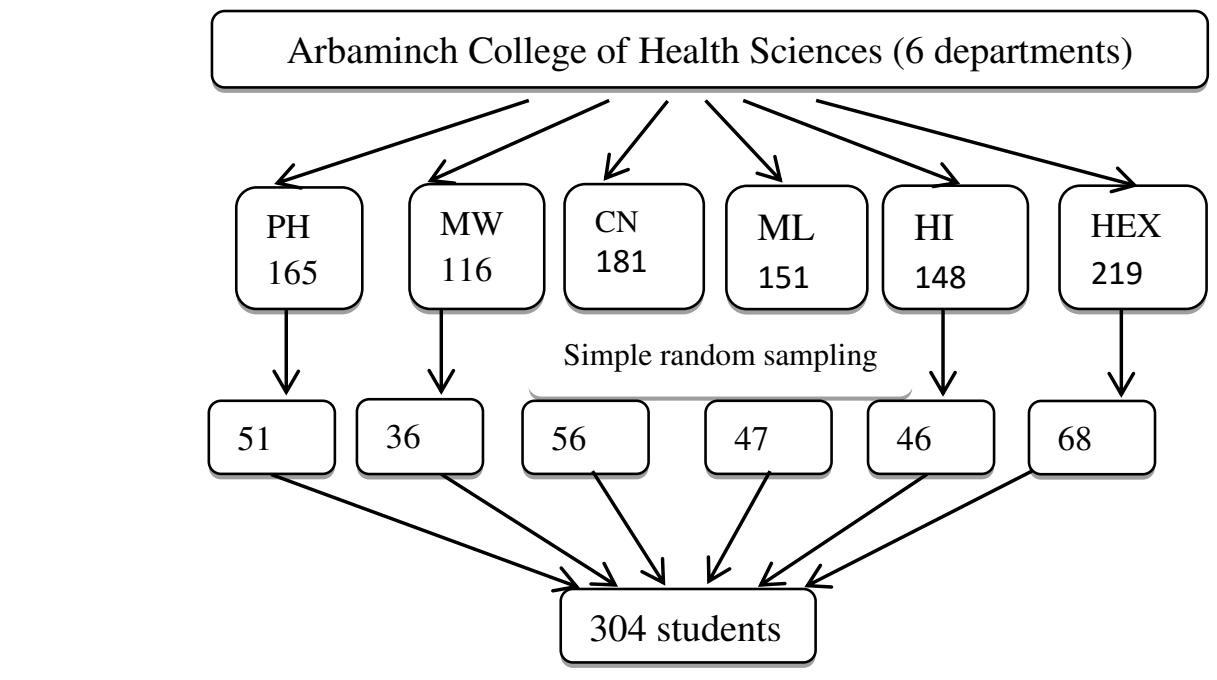

Figure 1: Schematic presentation of sampling procedure

PH-Pharmacy, MW-Midwifery, CN-Clinical nurse, ML-Medical laboratory, HI-Health informatics, HEX-Health extension department

\section{Data collection tool and procedure}

The questioner was structured, which was developed after several literature reviews [2, 9-12]. The questionnaire consisted of 33 items (10 items about demographic and education related and 23 items about knowledge on Novel Coronavirus). The tool was validated by performing pre-test on $10 \%$ of the sample before the real data collection time. Necessary adjustment of the questioner was carried out based on the pre-test results. Moreover, the reliability of the tool was tested, and their Cronbach Alpha value was 0.92. Data was collected by seven trained bachelor nurses employed from outside Arbaminch College of Health Sciences staffs who are fluent speaker of local language (Amharic) through face to face interview technique. To minimize bias data collectors were trained and emphasized to follow a standardize procedure. The data collectors collected the data using a structured interviewer administered Amharic version data 
149 collection tool. Two supervisors (MSc in Public health) and principal investigator closely 150 oversaw the process of data collection and confirms.

151 Data analysis

152 After the data collected, data were checked for fullness edited, coded and entered into Epi data $153 \quad 3.1$ and exported to Statistical Packages for Social Science version 20 for windows for analysis. 154 Descriptive analysis was performed on the socio-demographic, academic and knowledge related 155 variables such as sex, age, religion, marital status, last semester cumulative grade, department, 156 living arrangement, club participation, social media use and knowledge on the transmission, 157 prevention and control of novel coronavirus. Multivariable logistic regression analysis using, 158 backward stepwise method was used to choice independent variables to be involved in the last 159 model to identify the predictors that were independently related with the level of knowledge on 160 novel coronavirus. Odds ratios at $95 \% \mathrm{CI}$ were calculated to quantity the intensity of the association between the dependent and independent variables. P-values less than 0.05 were assumed as statistical significant in the multi variable logistic regression analysis.

163

164

165

166

167

168

169

170

171

172

173

174

175

176

177

178

179

173

\section{Operational definition}

Knowledge was measured by items concentrating on prevention, transmission, sign and symptoms, severity and treatment of the novel coronavirus infection. Each response was scored as 'yes (1)' or 'no/I don't know (0)'. The knowledge scoring range of the data collection tool was 23 (largest) to 0 (smallest). A cut off level of less than $11.5(<50 \%)$ was considered as poor whereas greater than or equal to $11.5(\geq 50 \%)$ was considered as good knowledge about novel coronavirus infection.

174

75

76




\section{Results}

\section{Socio-demographic and college related characteristics of study participants}

182 The socio-demographic and college related characteristics of the students were presented in 183 Table 1.In the current study, we assessed the knowledge about COVID-19 of 304 college 184 students, among them 167(54.9\%) and 137(45.1\%) were female and male, respectively.

185 The mean age $( \pm \mathrm{SD})$ of the respondents was $21.80( \pm 3.21)$ years, with $11(3.6 \%)$ students above

18630 years old. Most respondents came from rural area (68.4\%) and 69.7\% reported followers of 187 Protestant religion. Majority of respondents were single (71.7\%). The majority of participants 188 172(56.6) were use social media and 217(71.4\%) were non-members of the college clubs. More 189 than three fourth of the students $(87.8 \%)$ had cumulative grade greater than or equal $60 \%$. Sixty 190 one percent of the respondents were residing with their friends. Regarding department, 68 191 (22.4\%) of participants were Health Extension department and the lowest study participants 36 192 (11.8\%) were Midwifery departments.

193

194

195

196

197

198

199

200

201

202

203

204

205

206

207

208

209

210

211

212

213

214

215

216

217 
218 Table 1 Socio-demographic characteristics of the study participants at Arbaminch Health Science 219 College, Southwest Ethiopia, 2020.

220

\begin{tabular}{|c|c|c|}
\hline Variables & Number & Percent $(\%)$ \\
\hline \multicolumn{3}{|c|}{ Age(years) mean \pm SD $(21.80 \pm 3.21)$} \\
\hline $15-19$ & 49 & 16.1 \\
\hline $20-24$ & 209 & 68.8 \\
\hline $25-29$ & 35 & 11.5 \\
\hline$\geq 30$ & 11 & 3.6 \\
\hline \multicolumn{3}{|l|}{ Sex } \\
\hline Male & 137 & 45.1 \\
\hline Female & 167 & 54.9 \\
\hline \multicolumn{3}{|l|}{ Department } \\
\hline Pharmacy & 51 & 16.8 \\
\hline Health extension/Public health & 68 & 22.4 \\
\hline Midwifery & 36 & 11.8 \\
\hline Medical laboratory & 47 & 15.5 \\
\hline Clinical nursing & 56 & 18.4 \\
\hline Health informatics & 46 & 15.1 \\
\hline \multicolumn{3}{|l|}{ Marital status } \\
\hline Married & 86 & 28.3 \\
\hline Single & 218 & 71.7 \\
\hline \multicolumn{3}{|l|}{ Residence } \\
\hline Rural & 208 & 68.4 \\
\hline Urban & 96 & 31.6 \\
\hline \multicolumn{3}{|l|}{ Religion } \\
\hline Orthodox Christian & 74 & 24.3 \\
\hline Muslim & 18 & 5.9 \\
\hline Protestant & 212 & 69.7 \\
\hline \multicolumn{3}{|l|}{ Use of social media } \\
\hline Yes & 172 & 56.6 \\
\hline No & 132 & 43.4 \\
\hline \multicolumn{3}{|l|}{ Living } \\
\hline Alone & 65 & 21.4 \\
\hline With friend & 187 & 61.5 \\
\hline Family & 52 & 17.1 \\
\hline \multicolumn{3}{|l|}{ Club participation } \\
\hline Yes & 87 & 28.6 \\
\hline No & 217 & 71.4 \\
\hline \multicolumn{3}{|l|}{ Cumulative grade } \\
\hline$<60$ & 37 & 12.2 \\
\hline$\geq 60$ & 267 & 87.8 \\
\hline
\end{tabular}




\section{Knowledge of 2019-nCoV infection}

224

225

226

227

228

229

230

231

232

233

234

235

236

237

238

239

240

241

242

243

244

245

246

247

248

249

250

251

252

253

Only 97(31.9) of our respondents correctly knew that 2019-nCoV is a viral infection and only $22 \%$ knew its origin. In terms of awareness on transmission of COVID-19, only $43.4 \%$ of the participants were aware of 2019 novel coronavirus can transmitted by respiratory droplets when a diseased person sneeze or cough. Only 5.3\% of participants were able to response all the symptom knowledge items correctly (Q5 to Q8). In some detail cases, only 7.6\% of participants knew that muscle pain is a symptom of 2019-nCoV infection. One hundred forty three (47\%) of the participants did not know any symptoms of COVID-19. The vast majority (75.5\%) of the participants did not aware asymptomatic nature of the disease. The vast majority of students (78.3\%) had no knowledge of novel corona virus infection incubation period. Regarding the diagnosis of disease, only $33.9 \%$ of the participants correctly recognized that $2019-\mathrm{nCoV}$ infection diagnosed my molecular assays. Only $17.4 \%$ of the participants knew that novel corona vaccine is not available. In total, only $29.9 \%$ of the participants knew that a confirmed novel corona virus case should remain in isolation until retrieval from clinical symptoms of the infection.

Moreover, 249 (81.9\%) of the students had no information about the older people appear to be more vulnerable to becoming severely ill with the $2019-\mathrm{nCoV}$ infection. Only $33.9 \%$ of students knew that patients with underlying chronic diseases at a higher risk of $2019-\mathrm{nCoV}$ infection. Only $38.8 \%$ of students knew that washing hands with regular soap and water can help in prevention of disease transmission. Interestingly, only $24.3 \%$ of the respondents answered correctly that rubbing hands with alcohol based sanitizers can help in prevention of disease transmission. In terms of knowledge on prevention, only $26.3 \%$ of the students were aware of social-distancing (at least six feet) from anyone who is coughing or sneezing (Table 2). 
254 Table 2. Responses of the study participants to 2019-nCoV infection knowledge items,

255 Arbaminch College of Health Sciences ( $=304)$, Southwest Ethiopia, 2020.

\begin{tabular}{|c|c|c|}
\hline 2019-nCoV infection knowledge items & $\begin{array}{l}\text { Number } \\
\text { (correct } \\
\text { response) } \\
\end{array}$ & $\begin{array}{l}\text { Percent } \\
\text { (correct response) }\end{array}$ \\
\hline Q1.2019-nCoV is a viral infection & 97 & 31.9 \\
\hline Q2.2019-nCoV has its origin in bats & 67 & 22.0 \\
\hline $\begin{array}{l}\text { Q3.The first case of 2019-nCoV infection was first identified } \\
\text { in Wuhan, China }\end{array}$ & 150 & 49.3 \\
\hline $\begin{array}{l}\text { Q4.The virus can transmitted by respiratory droplets when an } \\
\text { infected person sneeze or cough }\end{array}$ & 132 & 43.4 \\
\hline Q5.Fever is a symptom of 2019-nCoV infection & 76 & 25.0 \\
\hline Q6.Cough is a symptom of 2019-nCoV infection & 87 & 28.6 \\
\hline Q7.Shortness of breath is a symptom of 2019-nCoV infection & 109 & 35.9 \\
\hline Q8.Muscle pain is a symptom of 2019-nCoV infection & 23 & 7.60 \\
\hline Q9.Diarrhea is a possible symptom of $2019-\mathrm{nCoV}$ infection & 64 & 21.1 \\
\hline $\begin{array}{l}\text { Q10.Some individuals infected with virus can be } \\
\text { asymptomatic }\end{array}$ & 74 & 24.3 \\
\hline Q11.The incubation period is $2-14$ days & 66 & 21.7 \\
\hline Q12.2019-nCoV infection diagnosed my molecular assays & 103 & 33.9 \\
\hline Q13.Antibiotics is not the first-line treatment & 75 & 24.7 \\
\hline Q14.2019-nCoV vaccine is not available & 53 & 17.4 \\
\hline $\begin{array}{l}\text { Q15.Confirmed novel corona virus cases should remain in } \\
\text { isolation until retrieval from clinical symptoms of COVID-19 }\end{array}$ & 91 & 29.9 \\
\hline $\begin{array}{l}\text { Q16.Individuals should be monitored for symptoms of } \\
\text { COVID-19 for } 14 \text { days after the contact with a patient with } \\
\text { proofed COVID- } 19 \text {. }\end{array}$ & 91 & 29.9 \\
\hline $\begin{array}{l}\text { Q17.Older people appear to be more vulnerable to becoming } \\
\text { severely ill with the } 2019-\mathrm{nCoV}\end{array}$ & 55 & 18.1 \\
\hline $\begin{array}{l}\text { Q18.Patients with underlying chronic diseases at a higher risk } \\
\text { of 2019-nCoV infection }\end{array}$ & 103 & 33.9 \\
\hline $\begin{array}{l}\text { Q19.Health care professionals face high risk of exposure to } \\
\text { COVID-19 }\end{array}$ & 104 & 34.2 \\
\hline $\begin{array}{l}\text { Q20.Washing hands with soap and water can help in } \\
\text { prevention of disease transmission }\end{array}$ & 118 & 38.8 \\
\hline $\begin{array}{l}\text { Q21. Rubbing hands with alcohol based sanitizers can help in } \\
\text { prevention of disease transmission }\end{array}$ & 74 & 24.3 \\
\hline $\begin{array}{l}\text { Q22.To prevent the spread of disease maintain at least } 6 \text { feet } \\
\text { distance from anyone who is coughing or sneezing is } \\
\text { mandatory }\end{array}$ & 80 & 26.3 \\
\hline $\begin{array}{l}\text { Q23.Health care professional providing care to 2019-nCoV } \\
\text { cases should ware personal protective (masks, gloves and } \\
\text { shoe cover, hair cover and aprons) }\end{array}$ & 132 & 43.4 \\
\hline
\end{tabular}


259 The vast majority of students $228(75 \%)$ scored below $50 \%$ and were considered to have poor

260 knowledge on COVID-19. Only 25\% had good knowledge on COVID-19(Figure 2).

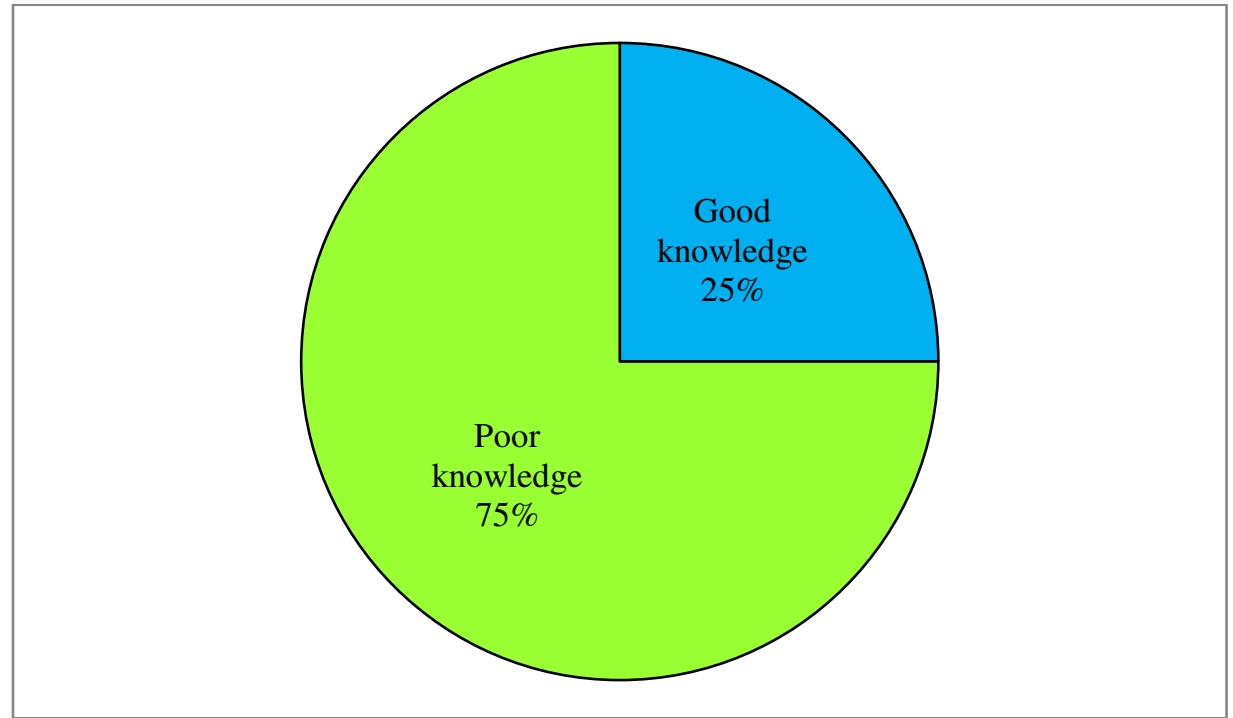

262 Figure 2: Knowledge level of respondents on novel corona virus, ACHS, 2020

263 The commonest source of information about novel coronavirus was from radio (42\%). Moreover,

264 internet, television, friend and newspaper accounted for 29\%, 22.4\%, 18.4\% and 1\%,

265 respectively (Figure 3).

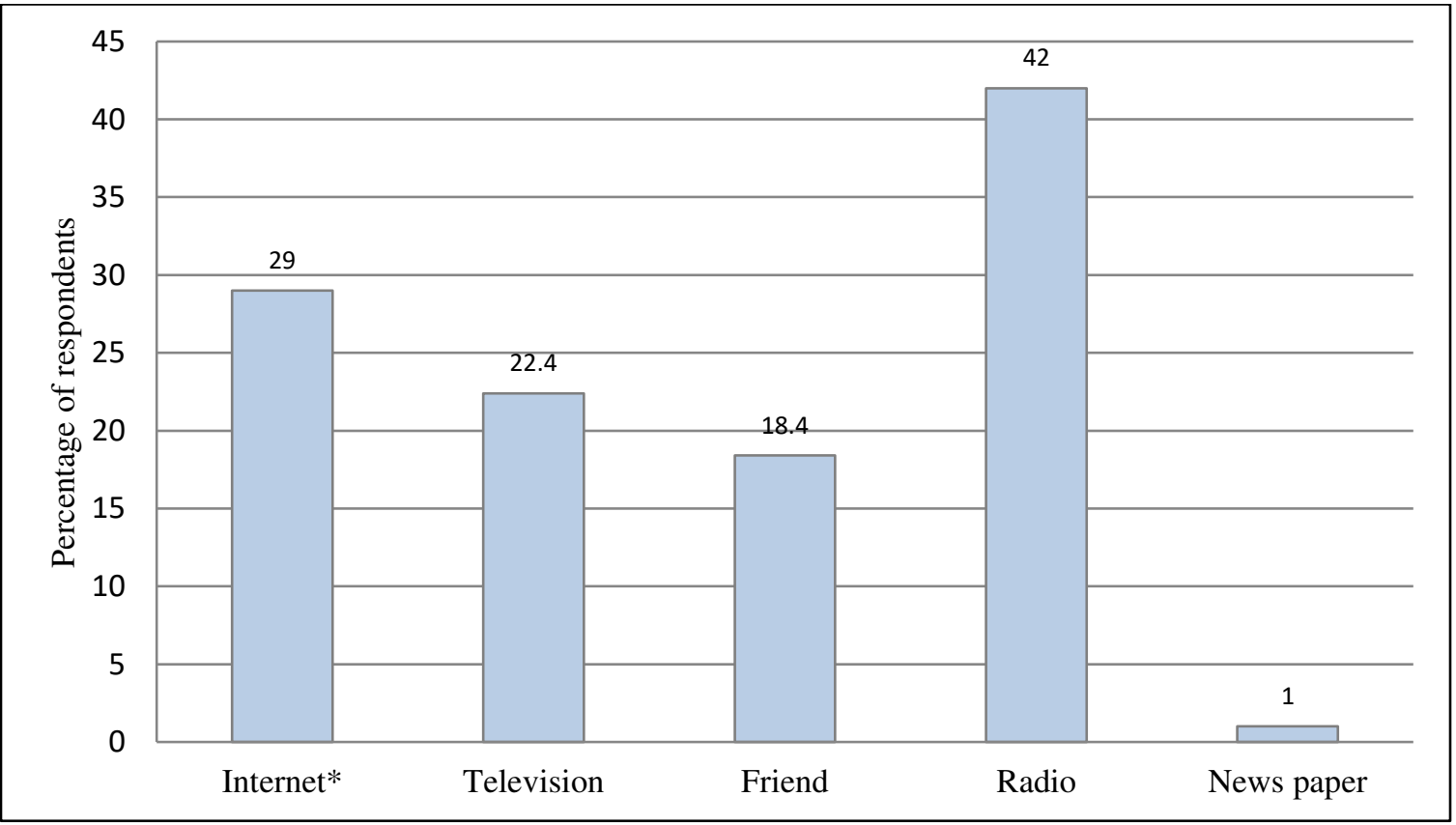

Internet* (social media and different websites) and multiple response data

Figure 3: Source of information about novel coronavirus among health science students in Arbaminch 


\section{Factors associated with knowledge of 2019-nCoV infection}

Table 3 displays the effect of factors on the COVID-19 knowledge adjusted for the other covariates. Socio-demographic and educational related predictors were tested using multi variable logistic regression for potential association. Female students were less likely to have good knowledge score as compared with male students [AOR: 0.3, 95\%CI: (0.2-0.6)]. Students who came from rural areas were less likely to have good knowledge scores as compared with students who were from the urban areas [AOR: 0.5, 95\%CI: (0.2-0.9)]. Students who were Muslim religion followers were 5.7 times more likely for having good knowledge score as compared to those who were Orthodox Christian students[AOR: 5.7, 95\%CI: (1.8-18.1)]. Students who were single were less likely to have good knowledge on novel corona virus infection than those students who were married [AOR: 0.4, 95\% CI: (0.2-0.9)].

Students with a high cumulative grade were more likely to have good knowledge on COVID-19 than those with a low commutative grade [AOR: 2.9, 95\%CI: (1.1-8.4)]. Those that were grouped as non-club participation were about 2.3 times more likely to have good knowledge on COVID-19 when compared to those who are members of the club [AOR: 2.3, 95\%CI: (1.1-4.6)]. Students who did not use social media were less likely to have good knowledge score when compared to those who used social media [AOR: 0.2, 95\%CI: (0.1-0.5)]. Students who were living with their family were 3.1 times [AOR: 3.1, 95\%CI: (1.2-7.7)] more likely to have good knowledge score as compared with students who were living alone. 
Table 3 Multi variable logistic regression analysis output of factors associated with knowledge of 2019-

nCoV infection among ACHS students, Southwest Ethiopia, 2020 $(n=304)$

\begin{tabular}{|c|c|c|c|c|}
\hline \multirow[t]{2}{*}{ Characteristics } & \multicolumn{2}{|c|}{ Knowledge on COVID-19 } & \multirow{2}{*}{$\begin{array}{l}\text { Adjusted odd ratio } \\
(95 \% \mathrm{CI})\end{array}$} & \multirow[t]{2}{*}{$p$-value } \\
\hline & Good n(\%) & Poor n(\%) & & \\
\hline \multicolumn{5}{|l|}{ Sex } \\
\hline Male & $45(32.8)$ & $92(67.2)$ & 1 & \\
\hline Female & $31(18.6)$ & $136(81.4)$ & $0.3(0.2-0.6)$ & $0.001^{* *}$ \\
\hline \multicolumn{5}{|l|}{ Age } \\
\hline $15-19$ & $14(28.6)$ & $35(71.4)$ & - & - \\
\hline $20-24$ & \begin{tabular}{|l|}
$50(23.9)$ \\
\end{tabular} & $159(76.1)$ & - & - \\
\hline$\geq 25$ & $12(26.1)$ & $34(73.9)$ & - & - \\
\hline \multicolumn{5}{|l|}{ Residence } \\
\hline Urban & $30(31.2)$ & $66(68.8)$ & 1 & \\
\hline Rural & 4 46(22.1) & $162(77.9)$ & $0.5(0.2-0.9)$ & $0.043^{*}$ \\
\hline \multicolumn{5}{|l|}{ Religion } \\
\hline Orthodox Christian & $22(29.7)$ & $52(70.3)$ & 1 & \\
\hline Protestant & $48(22.7)$ & $163(77.3)$ & $0.7(0.3-1.3)$ & 0.235 \\
\hline Muslim & 6(31.6) & $13(68.4)$ & $5.7(1.8-18.1)$ & $0.003^{* *}$ \\
\hline \multicolumn{5}{|l|}{ Marital status } \\
\hline Married & 19(22.1) & $67(77.9)$ & 1 & \\
\hline Single & $57(26.1)$ & 161(73.9) & $0.4(0.2-0.9)$ & $0.030^{*}$ \\
\hline \multicolumn{5}{|l|}{ Sponsor type } \\
\hline Self & $9(20.9)$ & $34(79.1)$ & - & - \\
\hline Government & $67(26.1)$ & 190(73.9) & - & - \\
\hline \multicolumn{5}{|l|}{ Department } \\
\hline Midwifery & $7(19.4)$ & $29(80.6)$ & - & - \\
\hline Pharmacy & $15(29.4)$ & $36(70.6)$ & - & - \\
\hline $\begin{array}{l}\text { Health } \\
\text { extension/Public } \\
\text { health }\end{array}$ & $12(17.6)$ & $56(82.4)$ & - & - \\
\hline Medical laboratory & $13(27.7)$ & $34(72.3)$ & - & - \\
\hline Clinical nursing & $10(17.9)$ & $46(82.1)$ & - & - \\
\hline Health informatics & 19(41.3) & $27(58.7)$ & - & - \\
\hline \multicolumn{5}{|l|}{ Cumulative grade } \\
\hline$<60$ & $6(16.2)$ & $31(83.8)$ & 1 & \\
\hline$\geq 60$ & $70(26.2)$ & 197(73.8) & $2.9(1.1-8.4)$ & $0.041^{*}$ \\
\hline \multicolumn{5}{|l|}{ Clubs participation } \\
\hline Yes & $20(23.0)$ & $67(77.0)$ & 1 & \\
\hline No & $56(25.8)$ & $161(74.2)$ & $2.3(1.1-4.6)$ & $0.022^{*}$ \\
\hline \multicolumn{5}{|l|}{ Social media use } \\
\hline Yes & $55(32)$ & $117(68.0)$ & 1 & \\
\hline No & 21(15.9) & 111(84.1) & $0.2(0.1-0.5)$ & $0.000^{* *}$ \\
\hline \multicolumn{5}{|l|}{ Living with } \\
\hline Alone & $15(23.1)$ & $50(76.9)$ & 1 & \\
\hline Friend & $42(22.5)$ & $145(77.7)$ & $0.5(0.2-1.1)$ & 0.098 \\
\hline Family & \begin{tabular}{|l|}
$19(36.5)$ \\
\end{tabular} & $33(63.5)$ & $3.1(1.2-7.7)$ & $0.015^{*}$ \\
\hline
\end{tabular}




\section{Discussion}

Throughout documented history, pandemics have persistently descended on human beings, troubling their existence. By March 13, 2020, a total of 132, 758 laboratory-confirmed cases and 4955 deaths had been documented globally [5]. Special consideration should be paid to health science students seeing their contribution to the nation's workforce in near future in a particular nation. Up to the best of our knowledge, and by exhaustive literature search, our study may be the first study conducted in Ethiopia for measuring knowledge of final year health science students towards novel coronavirus. Our study sought to assess knowledge towards novel coronavirus infection among health sciences students in Arbaminch College of Health Sciences, southwest Ethiopia. The results of this study showed that three fourth (75\%) of participating students had inadequate level of comprehensive knowledge score from the composite score concerning natural history of the disease, risky groups, symptoms, treatments and means of prevention of the infection. The possible explanation that can be recognized from the low level of knowledge regarding novel corona virus is that the curriculum of mid-level health students that had been prepared by ministry health has not stated coronavirus as content in the learning modules. Moreover, their teachers did not receive any novel coronavirus related on Job training.

Majority of the students in this study did not know that COVID-19 caused by virus. This result is consistent with other study that reported lack of knowledge about the causative agent among health science students in India [13]. A worrisome result in this research is that more than half of the participants did not know that novel coronavirus can transmitted by respiratory droplets when an infected person sneeze or cough, which is inconsistent with the results of Pranav D. et al,[13] who stated that more than $90 \%$ of students had knowledge of the transmission of novel coronavirus. Unaware of route of transmission of novel coronavirus infection will have negative influence on the control of the infection.

The WHO has encouraged isolation of persons with symptoms of novel coronavirus infection in order to minimize disease transmission and restrict the spread of the deadly virus in the community [9]. Accordingly, Ethiopian ministry of health rolled into action to stop the spread of the disease. Confirmed cases were isolated to break the transmission cycle. However, more than $70 \%$ respondents were not aware that a confirmed novel coronavirus case should remain in isolation until retrieval from clinical symptoms of the infection. This may lead to resistance to 
accept isolation/quarantine as one strategy for the virus control. In the present study, only $38 \%$ of the respondents did know that washing hands with regular soap and water can help in prevention of disease transmission. However, better finding was reported from the Mumbai study $(88.7 \%)$

342 [13].The reason behind such difference may be because some participant of the Mumbai study received hand hygiene training. Another important result revealed that only $26.3 \%$ students knew that the spread of the disease prevented by maintaining least 6 feet distance from anyone who is coughing or sneezing. This is consistent with the fact that the majority of students (56.6\%) were not aware of the disease transmission.

Only $43.4 \%$ of the participants knew that health care professional providing care to 2019$\mathrm{nCoV}$ cases should ware personal protective (masks, gloves and shoe cover, hair cover and aprons), which is again a major sign of concern. On the contrary Pranav D. et al. (2020) in India reported that $86.3 \%$ of the respondents had sufficient knowledge towards personal protective use during care to 2019-nCoV cases [13]. Possible reasons that can be attributed to this difference of response are demographic difference of the study population and study area. Knowing that specific prevention option and treatment, such as vaccines and targeted antiviral medicines, were not available for novel coronavirus infection, countries emphasized on traditional health outbreak response strategies (social-distancing, isolation and quarantine) [14, 15]. Therefore wide-ranging health education on the disease prevention and control is required.

Our finding shows that female students need to gain more knowledge about novel corona virus than male students. In this study, respondents who came from rural areas had poor knowledge on COVID-19 as compared with respondents who were from the urban areas. The probable reason for this difference can be that students from rural areas comparatively have lesser access to health information through electronic media. This finding reveals the need to pay attention to the accessibility of electronic media. Students who had cumulative grade greater than or equal 60 were about threefold more likely to have good knowledge scores as compared with students who had less than 60. This might be due to the fact that students who have good academic performance have the capacity to learn about new situation from different sources. The current 366 finding reveals that students who were members of college club had poor knowledge on novel coronavirus compared to those who were non-members. This implies that the college clubs 
media use may be useful for novel corona related knowledge. This finding could be due to the Ethiopia ministry of health's official face book has posted message regarding novel coronavirus. This result is in agreement with United State study where users of social media had more knowledge on health than non-users [16]. The college should encourage students to open their social media account (like face book and twitter) and follow the official social medias.

A number of governments have mentioned that health science students could be used health care systems affected by novel coronavirus [17]. Majority health care systems, like in Spain and Italy [18], are in catastrophe, and the rest expect extensive challenges in the coming months [19]. In this situation, students could be positioned in challenging conditions if requested to help health professionals in providing care. All the above statements suggest that the ministry of health should have been more alert in producing radio programs, television documentaries, newspaper reports and leaflets on this fatal virus to inform the students. Moreover, academic institutions should also make health education posts on this deadly virus through their websites and official face book address. Further, this finding reveals the need to pay consideration to the contents of the curriculum of the health science. The health science colleges should also promote learning of information seeking skills.

Our study has shared the drawbacks of cross-sectional studies (difficulty of determining causal associations between variables). In this study, sampling of students was limited to a single health science college. We do confess that if the study had been done in more health science colleges we would have get a more complete findings. Future studies could be aimed towards assessing attitude and practice toward the novel coronavirus infection among health science students.

\section{Conclusion}

Based on the outputs of the current study, it can be concluded that that lack of knowledge about COVID-19 among the health science students. Poor knowledge about COVID-19 was noted among students who were female, came from rural areas and non-user of social media. As the disease prevalence and death toll increase exponentially, health science college and health authorities should re-examine their capability to manage the deadly virus. 


\section{Declarations}

400 Ethics approval and consent to participate

401 We obtained ethical clearance was from Arbaminch Health Science College Ethical Review 402 Committee. Written informed consent was obtained from each participant prior to the interview. 403 For the purpose of confidentiality and ethical issues, names of respondents from which 404 information obtained were recorded and analyzed using uniquely identifying codes.

405 Consent for publication

406 Not applicable

407 Availability of data and materials

408 All data used to support the findings of this study are available.

409 Competing interests

$410 \quad$ No competing interest.

411 Funding

412 No financial support was gained.

\section{Authors' contributions}

414 BW participated in all stages of this manuscript development (conceptualization, design of the 415 study, analysis, supervision, validation, visualization, writing original draft, review and editing).

416 WT contributed to the design of the study, investigation, data analysis and writing the original 417 draft. WT, YC and KF participated in the data analysis, supervision and writing the original 418 draft. All authors review and approve the final manuscript.

419 Acknowledgements

420 We would like to acknowledge the support of Arbaminch health Science College in facilitating 421 data collection process. 


\section{References}

428 1. WMHC. Wuhan Municipal Health and Health Commission's Briefing on the Current Pneumonia Epidemic Situation in Our City. 2020. http://wjw.wuhan. gov.cn/front/web/show Detail/2019123108989.

2. Huang C, Wang Y, Li X, et al. Clinical features of patients infected with 2019 novel coronavirus in Wuhan, China. Lancet 2020; 395: 497-506.

3. WHO. Novel Coronavirus-China. 2020. https://www.who.int/csr/don/12-january-2020novel-coronavirus-china/en/.

4. WHO. Statement on the second meeting of the International Health Regulations (2005) Emergency Committee regarding the outbreak of novel coronavirus (2019-nCoV). 2020. https://www.who.int/news-room/detail/30-01-2020-statement-on-the-second-meeting-ofthe-international-healthregulations-(2005)-emergency-committee-regarding-the-outbreakof-novelcoronavirus-(2019-ncov).

5. WHO. Coronavirus disease 2019(COVID-19) situation report-53. 2020. https://www.who.int/docs/default-source/coronaviruse/situationreports/ 20200211-sitrep53-ncov.pdf?sfvrsn=fb6d49b1_2.

6. WHO report of the WHO china joint mission on corona virus disease 2019 (covid19).2020.

7. Gilbert M, Pullano G, Pinotti G, et al. Preparedness and vulnerability of African countries against importations of COVID-19: a modelling study.Lancet 2020; published online Feb 19. https://doi.org/10.1016/ S0140-6736(20) 30411-6.

8. WHO Regional office for Africa. First case of COVID-19 confirmed in Ethiopia. https://WWW.afro.who.int/news/first-case-covid-19-confirmed-ethiopia.

9. WHO. Clinical management of severe acute respiratory infection when novel coronavirus (2019-nCoV) infection is suspected.2020.

10. Huang C., Wang Y., Li X., Ren 8.L, Zhao J., Hu Y. Clinical features of patients infected with 2019 novel coronavirus in Wuhan, China. Lancet. 2020; 395: 497-506.

11. Li Q, Guan X, Wu P, Wang X, Zhou L, Tong Y, et al. Early Transmission Dynamics in Wuhan, China, of Novel Coronavirus-Infected Pneumonia. The New England Journal of Medicine. 202029 January 2020.

12. European Center for Disease Prevention and Control (ECDC).Guidelines for the use of non-pharmaceutical measures to delay and mitigate the impact of 2019-nCoV .February 2020.

13. Modi P D, Nair G, Uppe A, et al. (April 02, 2020) COVID-19 awareness among healthcare students and professionals in Mumbai metropolitan region: A questionnairebased survey. Cureus 12(4): e7514. DOI 10.7759/cureus.7514

14. McCloskey B, Heymann DL. SARS to novel coronavirus: old lessons and new lessons. Epidemiol Infect. 2020;148:e22. doi:10.1017/S0950268820000254. 
15. Wilder-Smith A, Freedman DO. Isolation, quarantine, social-distancing and community containment: pivotal role for old-style public health measures in the novel coronavirus (2019-nCoV) outbreak. J Travel Med. 2020. doi:10.1093/jtm/taaa020

16. Rosenbaum J, Johnson B, Deane A. Health literacy and digital media use: Assessing the Health Literacy Skills Instrument_ Short Form and its correlates among African American college students. Digital health. 4; 2018. DOI: 10.1177/2055207618770765.

17. Mahase E. Covid-19:Portugal closes all medical schools aftrer 31 cases confirmed in the country.BMJ.2020;368:M986

18. Remuzzi A. Remuzzi G COVID-19 and Italy: what next? Lancet. 2020. https://doi.org/10.1016/S0140-6736(20)306279

19. Representatives of the STARSurg Collaborative. Medical students involvement in the COVID-19 response. The Lancet.2020. DOI: https://doi.org/10.1016/S0140$\underline{6736(20) 30795-9}$

.

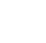


492 
Figures

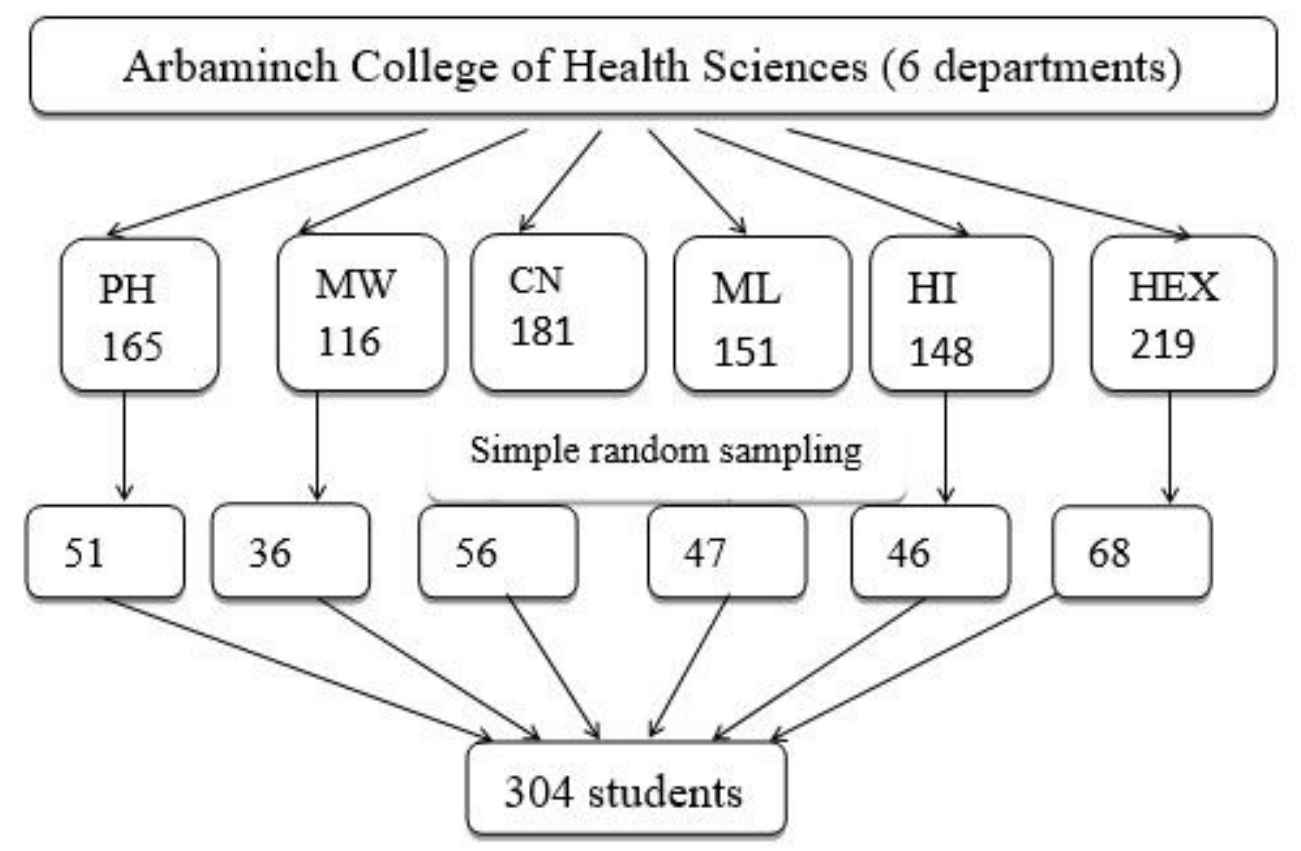

Figure 1

Schematic presentation of sampling procedure PH-Pharmacy, MW-Midwifery, CN-Clinical nurse, MLMedical laboratory, HI-Health informatics, HEX-Health extension department

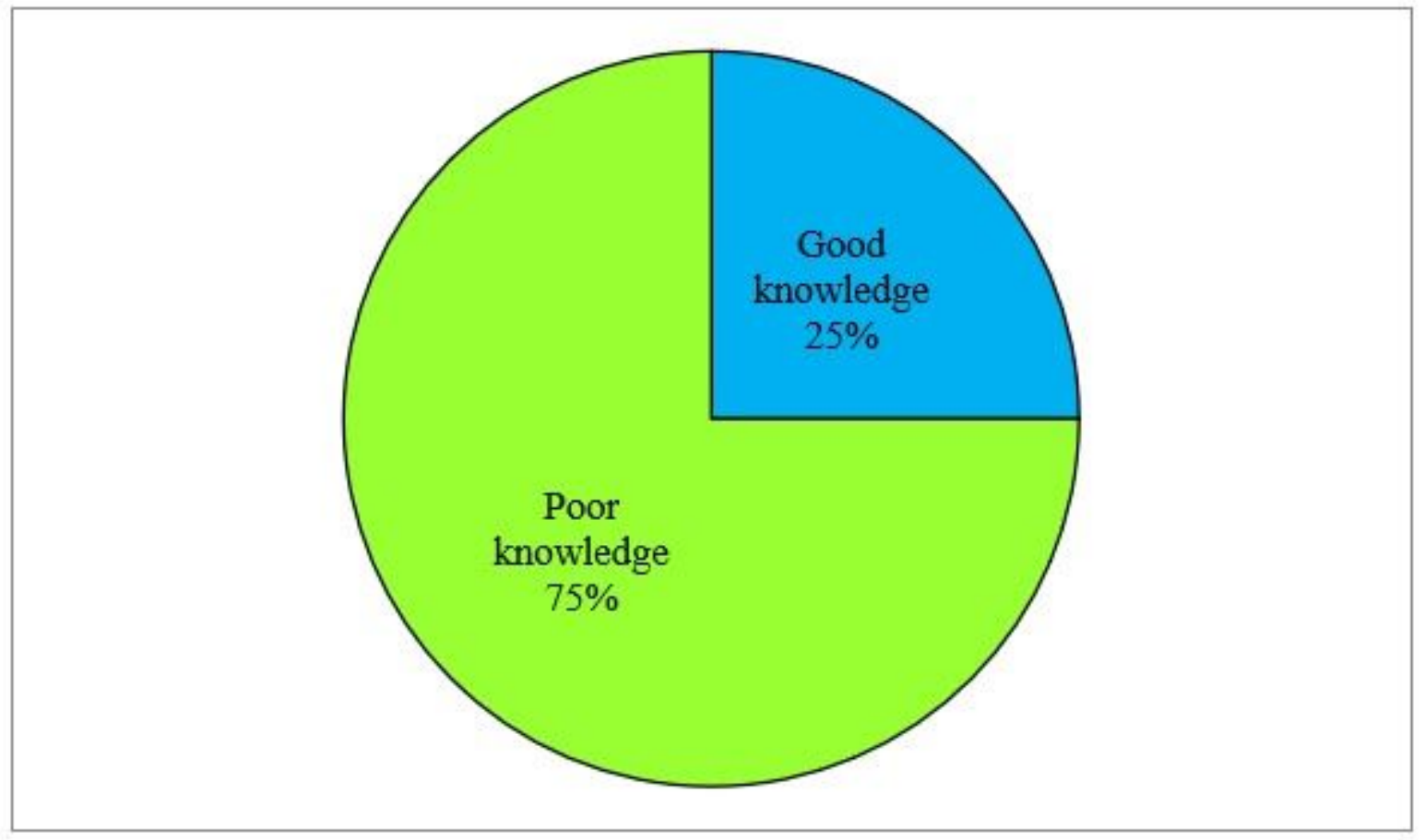

Figure 2 
Knowledge level of respondents on novel corona virus, ACHS, 2020 The commonest source of information about novel coronavirus was from radio (42\%). Moreover, internet, television, friend and newspaper accounted for $29 \%, 22.4 \%, 18.4 \%$ and $1 \%$, respectively (Figure 3 ).

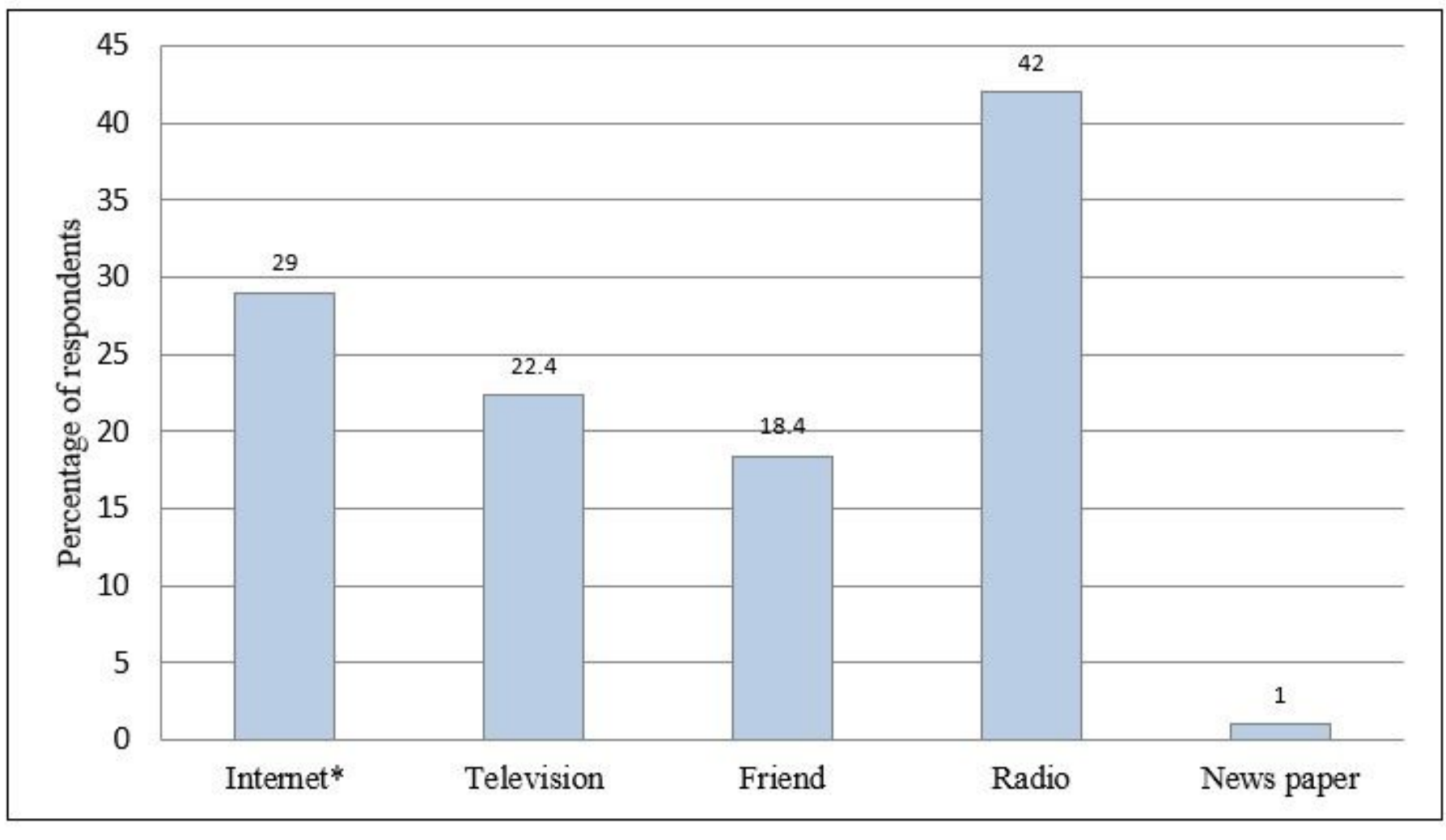

\section{Figure 3}

Internet* (social media and different websites) and multiple response data Figure 3: Source of information about novel coronavirus among health science students in Arbaminch College of Health Sciences, southwest Ethiopia 